DOI: $10.36910 / 6775-2524-0560-2020-40-22$

УДК: 004.056.5

Терейковська Людмила Олексіївна, к.т.н., доц.

http://orcid.org/0000-0002-8830-0790

Київський національний університет будівництва і архітектури

\title{
МЕТОД НЕЙРОМЕРЕЖЕВОГО РОЗПІЗНАВАННЯ ЕМОЦІЙ ПО ЗОБРАЖЕННЮ ОБЛИЧЧЯ
}

Терейковська Л.О. Метод нейромережевого розпізнавання емоцій по зображенню обличчя. Стаття присвячена вирішенню задачі вдосконалення нейромережевих засобів розпізнавання емоцій операторів інформаційно-управляючих систем на основі зображення обличчя. 3'ясовано, що труднощі розробки таких засобів пов'язані 3 формуванням репрезентативної навчальної вибірки. Запропоновано нівелювати означені труднощі за рахунок застосування експертних знань. Розроблено метод нейромережевого розпізнавання емоцій по зображенню обличчя людини, який за рахунок запропонованого підходу до застосування продукційних правил для подання в нейронну мережу експертних знань, дозволяє підвищити оперативність розпізнавання та розширити множину видів складних емоцій, характеристики яких не представлені в статистичних даних. Проведені експериментальні дослідження показали, що використання розробленого методу дозволяє забезпечити помилку розпізнавання емоцій на рівні кращих сучасних систем подібного призначення.

Ключові слова: розпізнавання емоцій, інформаційно-управляюча система, зображення обличчя, нейронна мережа, захист інформації, продукційне правило.

Терейковская Л.А. Метод нейросетевого распознавания эмоций по изображению лица. Статья посвящена решению задачи совершенствования нейросетевых средств распознавания эмоций операторов информационноуправляющих систем на основе изображения лица. Выяснено, что трудности разработки таких средств связаны с формированием репрезентативной обучающей выборки. Предложено нивелировать указанные трудности за счет применения экспертных знаний. Разработан метод нейросетевого распознавания эмоций по изображению лица человека, который за счет предложенного подхода к применению продукционных правил для подачи в нейронную сеть экспертных знаний, позволяет повысить оперативность распознавания и расширить множество видов сложных эмоций, характеристики которых не представлены в статистических данных. Проведенные экспериментальные исследования показали, что использование разработанного метода позволяет обеспечить ошибку распознавания эмоций на уровне лучших современных систем подобного назначения.

Ключевые слова: распознавание эмоций, информационно-управляющая система, изображение лица, нейронная сеть, защита информации, продукционное правило.

Tereikovska L.A. Neural network emotion recognition method based on facial images. The article is devoted to solving the problem of improving neural network means of recognizing emotions of operators of information control systems based on a face image. It was found that the difficulties in developing such tools are associated with the formation of a representative training sample. It is proposed to neutralize these difficulties through the use of expert knowledge. A method for neural network recognition of emotions based on the image of a person's face has been developed, which, due to the proposed approach to the application of production rules for supplying expert knowledge to the neural network, allows increasing the recognition efficiency and expanding many types of complex emotions, the characteristics of which are not presented in statistical data. Experimental studies have shown that the use of the developed method makes it possible to provide an error in emotion recognition at the level of the best modern systems for such a purpose.

Keywords: emotion recognition, information management system, face image, neural network, information security, production rule.

Постановка наукової проблеми. В даний час засоби автоматичного розпізнавання емоцій (ЗАРЕ) набувають все більшого поширення в інформаційно-управляючих системах (IУС) як загального так і спеціалізованого призначення. Наприклад, такі інструменти використовуються в деяких китайських школах для автоматичного виявлення учнів, які відволікаються від навчальних завдань [3, 4]. Також подібний інструментарій успішно використовується в медицині, індустрії розваг, системах управління розумним будинком та в галузі кібербезпеки для розпізнавання емоційного стану операторів критично важливих інфраструктурних об'єктів, ведення інформаційних війн та виявлення потенційних правопорушників в громадських місцях $[2,5]$.

У більшості відомих випадків розпізнавання емоцій реалізується на основі аналізу зображення обличчя людини. У той же час важливим напрямом підвищення ефективності 3АРЕ $\epsilon$ "інтелектуалізація" методів розпізнавання за допомогою використання нейромережевих рішень [1, 7]. Крім літературних джерел [8-11, 17-22], перспективність даного напрямку підтверджується успішним застосуванням нейромережевих 3APE в проектах «Oxford» (azure.microsoft.com/ruru/services/cognitive-services), «Noldus» (www.noldus.com/human-behavior-research/products/ facereader) та «Eyeris» (www.eyeris.ai). Разом з тим велика кількість хибних спрацювань, довготривалий термін та нестабільність навчання, недостатня адаптація до багатьох особливостей сучасного стану ІУС, що пов'язана в першу з методологічними недоліками, значно обмежують їх практичну цінність. 
Отже терміново слід вирішити проблему, викликану 3 одного боку необхідністю та перспективністю використання існуючих нейромережевих засобів розпізнавання емоцій, а з іншого недосконалістю методів розробки та застосування таких засобів.

Аналіз останніх досліджень і публікацій. В результаті аналізу науково-практичних робіт [8, $18,19]$, присвячених дослідженню апробованих рішень в області розпізнавання емоцій, визначено, що відомі методи розпізнавання можливо класифікувати на холістичні і локальні. Холістичні методи передбачають розпізнавання емоцій на підставі аналізу всього зображення в цілому. В локальних методах - емоції визначаються за сукупністю окремих контрольних точок або окремих частин зображення обличчя особи. При цьому в обох випадках найчастіше використовуються або засоби розпізнавання на основі логічних правил, або нейромережеві засоби, що базуються на класичних типах нейромережевих моделей (HМM). Крім того визначено, що в IУС загального призначення використовуються ЗАРЕ, що функціонують на основі аналізу статичного зображення обличчя, тобто динаміка зображення обличчя в часі не враховується. Це пояснюється труднощами реалізації безперервного відеоконтролю за обличчям конкретної людини. Також розглянуто ряд робіт, що присвячені сучасним ЗАРЕ на базі логічних правил. Так, в роботах $[5,14,17]$ наведено приклади використання теорії нечітких множин для розпізнавання базових емоцій. Вказано, що типовий набір нечітких логічних правил являє собою ряд різних варіантів реалізацій емоцій, складений на основі системи кодувань рухів обличчя (Action Units, AU), розробленої П. Екманом. Для кожної ознаки експериментально вибирають мінімальний поріг позитивної чи негативної вираженості, а потім складається логічне правило. Типовий приклад логічного правила визначається виразом:

$$
v=x_{1+} \wedge x_{2+} \wedge x_{14+} \wedge x_{20+},
$$

де $\wedge$ - логічний оператор «і»; | логічний оператор «або»; ! - логічний оператор «ні», $v$ - вид розпізнаної емоції, $\mathrm{x}_{i_{+}}$- $\mathrm{i}-и и ̆ ~ \mathrm{AU}$, позитивна вираженість якого перевищує мінімальне порогове значення.

Вказується, що для класифікації з використанням методів теорії нечіткої логіки першочергове значення має налаштування параметрів функцій приналежності, а також повнота експертних правил. Так, в [21] для настройки параметрів функцій приналежності пропонується використовувати покращений алгоритм Principal Component Analysis. Наведено результати експериментальних досліджень, відповідно до яких середня точність розпізнавання семи емоцій становить 98,32\%. Подібний підхід до класифікації запропонований в [15]. В цьому випадку ступінь вираженості AU перетворюється в маркери наявності емоцій за допомогою логічних дерев рішень, специфічних для різних етнічних груп. Разом з тим вказується, що значною перешкодою в розробці подібних засобів $\epsilon$ необхідність створення представницьких баз даних нечітких експертних правил, що враховують різноманіття умов розпізнавання. Для подолання вказаної перешкоди використовуються нейромережеві ЗАРЕ, для аналізу яких використано роботи [1, 8-13, 26-28]. Так, в [1] запропонований варіант реалізації засобів розпізнавання емоційного стану для підвищення ергономічності системи підтримки спілкування людини з сервісами антропоморфних роботів. Вказується, що суттєвою перешкодою при розробці систем розпізнавання емоцій є обмеженість доступних баз даних, а також висока частка індивідуальних особливостей в прояві тієї чи іншої емоції у різних людей. Це істотно підвищує вимоги до узагальнюючих можливостей використаних методів машинного навчання. Крім цього на точність розпізнавання суттєво впливає зміна положення особи на зображенні, наявність окулярів, макіяжу або зачіски, яка закриває брови. Для нівелювання цих труднощів пропонується використовувати різні алгоритми локальної фільтрації зображення при визначенні інформативних ознак особи, а оцінку ступеня вираженості емоцій - розраховувати за допомогою мультикласифікатора. Розроблена в [12] система дозволяє розпізнавати 7 базових емоцій на основі відфільтрованих локальних ознак ступеня вираженості 20 AU. До вказаних базових емоцій відносять радість, злість, смуток, відразу, страх та здивування. Отримані значення нормують відповідно нейтрального виразу обличчя, а потім розраховували ступінь вираженості кожної з базових емоцій класифікаторами трьох типів: класифікатором Байєса, двохшаровим персептроном і блоком логічних правил. Підсумкова ступінь вираженості емоції розраховується як сума відгуків класифікатором Байєса і нейронної мережі. Логічні правила використовуються тільки для вирішення ситуацій, коли кілька емоцій отримують однакову високу оцінку ступеня вираженості. Експериментально доводиться, що сам по собі блок логічних правил не дозволяє досягти достатньої точності розпізнавання. Тому самостійне використання такого блоку в роботі [12] вважають недоцільним. Вказано, що досягнута точність класифікації емоцій системи в цілому складає 85\%. Автори [21] декларують можливість значного підвищення точності розпізнавання за рахунок використання в якості ознак просторово-часової модифікації локальних бінарних шаблонів. В $[9,18]$ 
продемонстровано алгоритм розрахунку інтенсивності $\mathrm{AU}$ i нейромережевого зіставлення ефективності різних груп ознак і їх об'єднань.

Результати проведеного аналізу дозволяють стверджувати, що в області нейромережевого розпізнавання емоцій основна увага сконцентрована на оптимізацію структурних параметрів НММ та на створення засобів попередньої фільтрації зображень. При цьому базою сучасних рішень $\epsilon$ згорткові нейронні мережі різної архітектури. Інші типи апробованих НММ менш ефективні як 3 точки зору точності розпізнавання, так і з точки зору ресурсоємності. Також вважається, що важливою передумовою ефективного розпізнавання емоцій за допомогою НMМ $\epsilon$ наявність відкритих і представницьких баз даних, які можуть бути використані для навчання і тестування мережі. Найбільш відомими із них є OMG-Emotion challenge, EmotiW challenge, AffectNet, AFEW-VA, EmotioNet challenge, EmoReact, Cohn-Kanade. У зазначених базах кількість представлених емоцій варіюється від 6 до 17. Разом з тим в більшості із проаналізованих робіт [12-17, 23-28] вказується на недостатню репрезентативність баз даних, що не дозволяє проводити ефективне навчання НММ для розпізнавання емоцій при негативному впливі завад, характерних для ІУС (поворот обличчя та розмитість зображення обличчя). В результаті втрачається оперативність створення нейромережевих засобів розпізнавання. Виправити вказаний недолік можливо по аналогії з [2, 5], де недостатня повнота баз даних параметрів кібератак нівелюється за рахунок подання в НММ експертних правил. Ще одним позитивним моментом навчання НMМ на експертних даних $є$ можливість розпізнавання складних емоцій, статистика яких недостатньо представлена в відомих базах даних.

Мета дослідження. Розробка методу нейромережевого розпізнавання емоцій по зображенню обличчя оператора інформаційно-управляючої системи, що за рахунок використання експертних знань забезпечить підвищення оперативності розпізнавання та дозволить розширити множину видів складних емоцій, характеристики яких не представлені в статистичних даних.

Виклад основного матеріалу й обгрунтування отриманих результатів.

Концептуально теорія нейронних мереж об'єднує багато різнотипних моделей. Спільною рисою НММ є методологія обробки даних, яка полягає в отриманні зовнішнього сигналу, його передачі до штучних нейронів по синаптичним зв'язкам, обробці в штучному нейроні отриманого сигналу шляхом застосування активаційної функції. При цьому кожен синаптичний зв'язок може мати свій унікальний ваговий коефіцієнт, попередньо визначений при навчанні НММ в процесі подання навчальних прикладів. Саме багатоітераційна процедура подання деяким типам НММ навчальних прикладів (статистичних даних) $є$ підгрунтям для їх інтерпретації як аналізатора статистичної інформації. До цих типів НММ передусім відносяться багатошаровий персептрон, карта Кохонена, згорткова та рекурентна нейронна мережа. Однак достатньо відомі та апробовані інші типи НMМ, котрі навчаються методом "з вчителем" шляхом запам'ятовування представлених навчальних прикладів, які в певному сенсі можна вважати аналогом продукційних правил типу (1). Адже по своїй суті навчальний приклад - це комбінація продукційних правил:

$$
\text { If } X_{1}=a_{1} \wedge X_{2}=a_{2} \wedge \ldots \rightarrow Y,
$$

де $X_{i}$ - і-ий вхідний параметр (атрибут), $Y$ - вихід НMМ, $a_{i}$ - задане значення і-го параметру.

Таким чином, в НММ, що навчаються шляхом запам'ятовування навчальних прикладів, можливо подати експертні знання у вигляді продукційних правил.

Найбільш відомим типом таких НMМ є ймовірнісна нейронна мережа (PNN - Probabilistic Neural Network). Класифікація невідомих прикладів реалізується мережею PNN на основі оцінок їх схожості з навчальними прикладами за допомогою методу Байєса $[3,5,25]$. Невідомий приклад відноситься до класу, у якого щільність розподілу в області даного прикладу є найбільшою. Для оцінки щільності розподілу в області певного навчального прикладу використовується функція Гауса 3 центром в точці, якій відповідає даний приклад. Класична мережа PNN складається із чотирьох шарів нейронів - вхідного, образів, додавання та вихідного. Кількість нейронів вхідного шару $\left(L_{i n}\right)$ дорівнює кількості контрольованих параметрів. Кількість нейронів шару образів $\left(L_{o}\right)$ дорівнює кількості навчальних прикладів, а кількість нейронів шару додавання $\left(L_{s}\right)$ дорівнює кількості класів, які розпізнаються. Шари $L_{\text {in }}$ та $L_{o}$ складають повнозв'язну структуру, а кожен нейрон шару $L_{o}$ пов'язаний тільки з тим нейроном шару $L_{s}$, якому відповідає клас образу. Для зв'язків, що входять в нейрон $L_{o}$, вагові коефіцієнти встановлюються такими ж, як нормалізовані складові частини відповідного навчального прикладу. Вагові коефіцієнти зв'язків, що входять до нейронів $L_{s}$ та до нейрону вихідного шару $\left(L_{\text {out }}\right)$ дорівнюють 1 . Таким чином, структура і вагові коефіцієнти зв'язків мережі PNN безпосередньо визначаються навчальними даними. Структура мережі PNN, призначеної для класифікації двох абстрактних класів показана на рис. 1. Нейрони шару $L_{o} 3$ номерами від $\mathrm{A}_{1}$ до 
$\mathrm{A}_{\mathrm{N}}$ відповідають навчальним прикладам, які співвідносяться з класом $\mathrm{A}$, а нейрони з номерами від $\mathrm{B}_{1}$ до $\mathrm{B}_{\mathrm{N}}$ - 3 класом В. Вихідний сигнал ј-го нейрону шару образів розраховується так:

$$
\theta_{j}^{o}=\sum_{i=1}^{N} \exp \left(\frac{-\left(w_{i, j}-x_{i}\right)^{2}}{2 \sigma^{2}}\right),
$$

де $x_{i}-i$-а компонента невідомого образу, $w_{i, j}$ - ваговий коефіцієнт зв'язку між $i$-им вхідним нейроном та $j$-им нейроном шару образів, $N$ - кількість компонент вхідного вектора-образу, $\sigma-$ радіус функції Гауса.

Вихідний сигнал ј-го нейрону в шарі $L_{s}\left(\theta_{j}^{s}\right)$ розраховується так:

$$
\theta_{j}^{s}=\sum_{i=1}^{N} \theta_{i}^{o}
$$

де $N$ - кількість нейронів $L_{o}$, пов'язаних з ј-им нейроном $L_{s}, \theta_{i}^{o}$ - активність і-ого нейрону шару образів, пов'язаного з ј-им нейроном $L_{s}$.

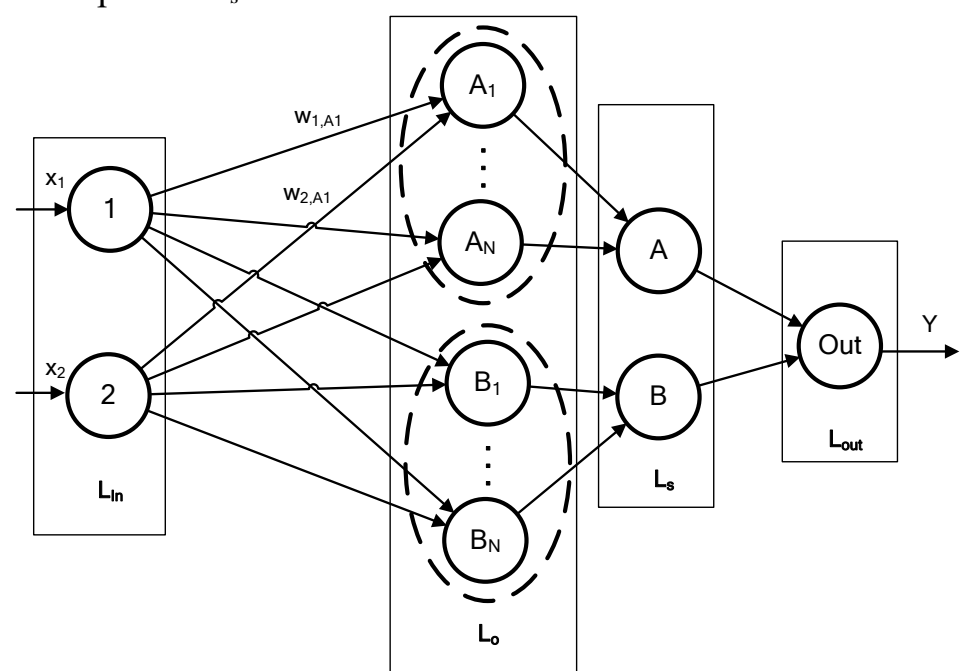

Рис. 1. Структура мережі PNN, що призначена для розпізнавання двох класів

Вихідний сигнал нейрону шару $L_{s}$ дорівнює ймовірності віднесення вхідного образу до класу, що відповідає даному нейрону. Задачею вихідного нейрону $є$ тільки визначення нейрону $L_{s} 3$ максимальною активністю. В багатьох випадках вихідний нейрон відсутній, а визначення нейрону $L_{s}$ з максимальною активністю реалізують засобами, які не входять до складу НМ.

Зазначимо, що відповідно $[3,5]$ для підвищення ефективності процесу розрахунку вихідного сигналу мережу PNN доцільно представити в матричній формі. При цьому елементами матриць будуть вагові коефіцієнти зв'язків між сусідніми шарами нейронів. Якщо ж зв'язок між нейронами не передбачено, то вважається, що його ваговий коефіцієнт дорівнює 0. Єдиним емпіричним параметром такої моделі мережі PNN є величина радіуса функції Гауса, що використовується у виразі (3) для розрахунку вихідного сигналу нейрону шару образів. При цьому для багатьох практичних випадків можна прийняти $\sigma=1$.

На основі результатів $[2,25]$ можливо стверджувати, що особливості структури та навчання НММ дозволяють реалізувати внесення в неї нового продукційного правила (навчального прикладу), використовуючи підхід:

- Співвіднести вхідні нейрони PNN 3 атрибутами продукційних правил.

- Співвіднести нейрони шару додавання 3 класами, до яких може бути віднесений невідомий приклад.

- Співвіднести результат нового продукційного правила з одним із нейронів шару додавання.

- Додати в шар образів новий нейрон, що відповідає новому продукційному правилу.

- Задати для цього нейрону величини вагових коефіцієнтів вхідних зв'язків рівними значенням атрибутів даного продукційного правила.

- Встановити для нового нейрону вихідний зв'язок з відповідним нейроном шару додавання.

Базуючись на наведеному підході та 3 урахуванням теоретичних робіт [1, 23-25], запропоновано метод нейромережевого розпізнавання емоцій по зображенню обличчя, що складається 3 наступних етапів: 
1. Використовуючи технології обробки експертної інформації визначити:

- Множину параметрів, що описують геометрію обличчя.

- Множину емоцій, яку повинна розпізнавати НММ. В найпростішому випадку НМ буде розпізнавати сім базових емоцій.

- Множину продукційних правил вигляду (2).

2. Визначити множину вхідних параметрів НММ, що співвідносяться 3 параметрами, що описують геометрію обличчя. При цьому можливо застосувати запропонований в [1] метод кодування рухів обличчя.

3. Визначити в шарі додавання стільки нейронів, скільки класів (емоцій) повинна розпізнавати HMM.

4. Використовуючи наведений підхід визначити структуру та вагові коефіцієнти зв’язків.

Запропонований метод верифіковано експериментальним шляхом. Проведені комп'ютерні експерименти, спрямовані на нейромережеве розпізнавання семи базових емоцій на основі аналізу 46 AU. Структура побудованої HMM типу PNN показана на рис. 2.

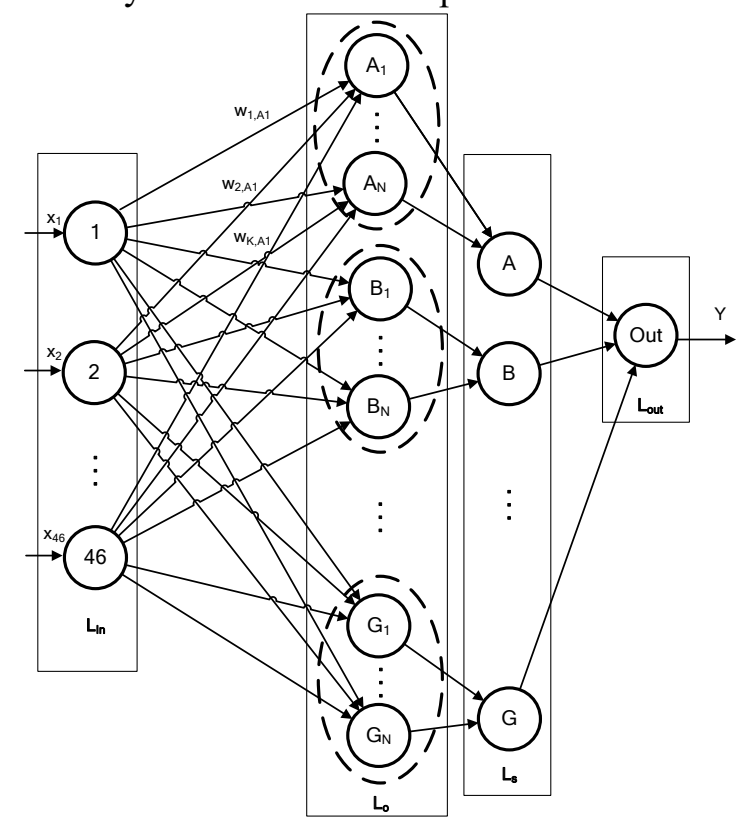

Рис. 2. Структура мережі PNN, призначеної для класифікації базових емоцій

В даній мережі нейрони вхідного шару відповідають окремим AU. Так в шарі додавання нейрон А відповідає емоції радість, В - гніву, C - огиді, D - смутку, Е - страху, F - здивуванню, а нейрон $\mathrm{G}$ - нейтральності. Для навчання розроблено продукційні правила виду:

$$
\begin{aligned}
& \text { If } X_{1}=0 \wedge \ldots X_{4}=1 \wedge X_{5}=1 \wedge X_{6}=0 \\
& \wedge X_{7}=1 \wedge X_{8}=0 \ldots \wedge X_{17}=1 \wedge X_{18}=0 \ldots \\
& \wedge X_{23}=1 \wedge X_{24}=0 \ldots \wedge X_{46}=0 \rightarrow \text { Padicmb }
\end{aligned}
$$

де $X_{i}=0$, коли інтенсивність і-го $\mathrm{AU}$ не перевищує пороговий рівень, $X_{i}=1$, коли інтенсивність і-го AU більша порогового рівня.

Зазначимо, що кожній емоції співставлено 6 продукційних правил. Відповідно кількість нейронів у шарі образів дорівнює 42. В якості джерела експертних даних використано роботи [12, 19 , 27]. Апробація розробленої моделі на даних БД Fer2013-images (www.kaggle.com) показала точність розпізнавання на рівні 85\%. При цьому всі зображення, що були використані для формування навчальних прикладів, розпізнані з точністю $100 \%$. Не зважаючи на можливості подання експертних знань, широкому застосуванню запропонованого методу дещо заважає використання в ньому мережі PNN, характерний недолік якої полягає у низькій здатності узагальнювати навчальну інформацію. Це заважає використовувати запропонований метод для однієї із найбільш актуальних задач в області біометрії - одночасного оперативного розпізнавання емоцій багатьох людей $[2,25]$. Тому доцільно співвіднести шляхи подальших досліджень 3 вдосконаленням запропонованого методу в напрямку застосування НММ з високими узагальнюючими можливостями.

Висновки та перспективи подальших досліджень. Проблематика статті пов'язана 3 вдосконаленням засобів розпізнавання емоційного стану операторів інформаційно-управляючих систем. Показано, що з позицій ергономічності, продуктивності та захищеності впровадження 
вказаних засобів дозволить підвищити ефективність як універсальних, так i iнформаційноуправляючих систем, котрі використовуються на об'єктах критичної інфраструктури. Визначено перспективність засобів розпізнавання емоційного стану на основі нейромережевого аналізу зображення обличчя оператора. 3'ясовано, що труднощі розробки таких засобів пов'язані 3 формуванням репрезентативної навчальної вибірки. Запропоновано нівелювати означені труднощі за рахунок застосування експертних знань. Для цього запропоновано оригінальний підхід застосування продукційних правил для подання в нейронну мережу експертних знань. На базі запропонованого підходу побудовано метод нейромережевого розпізнавання емоцій по зображенню обличчя людини, який дозволяє підвищити оперативність розпізнавання та розширити множину видів складних емоцій, характеристики яких не представлені в статистичних даних. Проведені експериментальні дослідження показали, що використання побудованого методу дозволяє забезпечити помилку розпізнавання емоцій на рівні відомих розробок аналогічного призначення. Запропоновано співвіднести шляхи подальших досліджень 3 розробкою рішень, що дозволили б одночасно оперативно розпізнавати емоції багатьох людей.

\section{Список бібліографічних посилань.}

1. Бобе А.С., Конышев Д.В., Воротников С.А. Система распознавания базовых эмоций на основе анализа двигательных единиц лица. Инженерный журнал: наука и инновации, 2016, вып. 9. pp. 1-16.

2. Корченко А., Терейковский И., Карпинский Н., Тынымбаев С. Нейросетевые модели, методы и средства оценки параметров безопасности интернет-ориентированных информационных систем. [Монография] - К.: Наш Формат, 2016. $-273 \mathrm{c}$.

3. Міхайленко В. М., Терейковська Л. О., Терейковський І. А., Ахметов Б. Б. Нейромережеві моделі та методи розпізнавання фонем в голосовому сигналі в системі дистанційного навчання: [Монографія] - К.: ЦП «Компринт», 2017.- $252 \mathrm{c}$.

4. Михайленко В. М., Терейковская Л.А. Парадигмы нейросетевого распознавания эмоций. Управління розвитком складних систем. 2019. №39. сс. 179-186.

5. Терейковський І. Нейронні мережі в засобах захисту комп’ютерної інформації.-К.: ПоліграфКонсалтинг, 2007.-209 с.

\section{References.}

1. Akhmetov B., Tereikovskyi I., Tereikovska L., Adranova A. Neural Network User Authentication by Geometry of the Auricle. Recent Developments in Data Science and Intelligent Analysis of Information Proceedings of the XVIII International Conference on Data Science and Intelligent Analysis of Information, June 4-7, 2018, Kyiv, Ukraine, pp.11-19.

2. Akhmetov B., Tereykovsky I. , Doszhanova A., Tereykovskaya L. (2018). Determination of input parameters of the neural network model, intended for phoneme recognition of a voice signal in the systems of distance learning. International Journal of Electronics and Telecommunications. Vol 64, No 4 (2018), pp. 425-432.

3. Anderson K., McOwan Peter W. A realtime automated system for the recognition of human facial expressions // Systems, Man, and Cybernetics, Part B: Cybernetics, IEEE Transactions on , vol.36, no.1, pp.96-105, 2006.

4. Batista J., Albiero V., Bellon O., Silva L. Aumpnet: simultaneous action units detection and intensity estimation on multipose facial images using a single convolutional neural network. In Automatic Face \& Gesture Recognition (FG 2017), 2017 12th IEEE International Conference on, pages 866-871. IEEE, 2017.

5. Chandrani S., Washef A., Soma M., Debasis M. Facial Expressions: A Cross-Cultural Study. Emotion Recognition: A Pattern Analysis Approach. Wiley Publ., 2015, pp. 69-86.

6. Dychka I., Tereikovskyi I., Tereikovska L., Pogorelov V., Mussiraliyeva S. (2018). Deobfuscation of computer virus malware code with value state dependence graph. Advances in Intelligent Systems and Computing, pp. 370-379, 2018.

7. Ertugrul O., Jeni L., Cohn J. FACSCaps: Pose-Independent Facial Action Coding with Capsules. 2018 IEEE/CVF Conference on Computer Vision and Pattern Recognition Workshops (CVPRW), Salt Lake City, UT, 2018, pp. 2211221109.

8. Ghosh S., Laksana E., Scherer S., Morency L.-P. A multi-label convolutional neural network approach to crossdomain action unit detection. In Affective Computing and Intelligent Interaction, 2015 International Conference on, pages 609-615. IEEE, 2015.

9. Goodfellow J., Erhan D., Carrier L. (2015). Challenges in representation learning: A report on three machine learning contests, Neural Networks 2015, vol. 64, pp. 59-63.

10. Gudi A., Tasli H., Den Uyl T., Maroulis A. Deep learning based facs action unit occurrence and intensity estimation. In Automatic Face and Gesture Recognition (FG), 2015 11th IEEE International Conference and Workshops on, vol. 6, pp. 1-5.

11. He J., Li D., Yang B., Cao S., Sun B., Yu L.. Multi view facial action unit detection based on cnn and blstmrnn. In Automatic Face \& Gesture Recognition (FG 2017), 2017 12th IEEE International Conference on, pages 848-853. IEEE, 2017.

12. Hu Z., Tereykovskiy I., Tereykovska L., Zhibek A. Optimization of convolutional neural network structure for biometric authentication by face geometry. Advances in Intelligent Systems and Computing. 2018. Volume 754, pp 567-577.

13. Ilbeygi M., Shah-Hosseini H. A novel fuzzy facial expression recognition system based on facial feature extraction from color face images. Engineering Applications of Artificial Intelligence 25, 2012, pp. 130-146.

14. Erik L., Gary B., RoyChowdhury A., Haoxiang L. Labeled Faces in the Wild: A Survey. In Advances in Face Detection and Facial Image Analysis, Springer, pages 189-248, 2016.

15. Seyed M., Marjan A., Face emotion recognition system based on fuzzy logic using algorithm improved Particle Swarm, International Journal of Computer Science and Network Security, V. 16 No.7, July 2016, pp. 157-166.

16. Tariq U., Lin K., Li Z., Zhou Z., Wang Z., Le V., Huang T.S., Lv X., Han T.X. Emotion Recognition from an Ensemble of Features. Systems, Man, and Cybernetics, Part B: Cybernetics, IEEE Transactions, 2012, vol. 42 (4), pp. 1017-1026. 
17. Tereikovska L., Tereikovskyi I., Mussiraliyeva S., Akhmed G. Recognition of emotions by facial Geometry using a capsule neural network. International Journal of Civil Engineering and Technology (IJCIET). Vol. 10, Issue 04, April 2019, pp. 270279

18. Tereykovska L., Tereykovskiy I., Aytkhozhaeva E., Tynymbayev S., Imanbayev A. (2017). Encoding of neural network model exit signal, that is devoted for distinction of graphical images in biometric authenticate systems. News of the National Academy of Sciences of the Republic of Kazakhstan, Series of Geology and Technical Sciences, Volume 6, Number 426, pp. $217-224,2017$.

19. Tereykovskaya L., Petrov O., Aleksander M. Prospects of neural networks in business models. TransComp 2015. 30 November - 3 December, 2015, Zakopanem, Poland. - P. 1539-1545.

20. Toliupa S., Tereikovskiy I., Dychka I., Tereikovska L., Trush A. The Method of Using Production Rules in Neural Network Recognition of Emotions by Facial Geometry. 3rd International Conference on Advanced Information and Communications Technologies (AICT). 2019, 2-6 July 2019, Lviv, Ukraine, Page(s): 323 - 327

21. Toser Z., Jeni L., Lorincz A., Cohn F. Deep learning for facial action unit detection under large head poses. In European Conference on Computer Vision, pages 359-371. Springer, 2016.

22. Wang Z., Li Y., Wang S., Ji Q.. Capturing global semantic relationships for facial action unit recognition. In Computer Vision (ICCV), 2013 IEEE International Conference on, pages 3304-3311. IEEE, 2013.

23. Zhao K., Chu W., Zhang H.. Deep region and multilabel learning for facial action unit detection. 2016 IEEE Conference on Computer Vision and Pattern Recognition (CVPR), Las Vegas, NV, 2016, pp. 3391-3399. 